\title{
(+)-Usnic Acid Isolated from the Lichen Cladonia substellata Impairs Myocardial Contractility
}

\section{(ㄷ) (2) (i) (ㅇ)}

\author{
Authors \\ Sílvia Caroline Santos Mendonça ${ }^{1}$, Carla Maria Lins de Vasconcelos ${ }^{1}$, Jader Santos Cruz², Danilo Roman-Campos ${ }^{3}$, \\ José Evaldo Rodrigues Menezes-Filho', Robson Araújo Anjos-Neto', Diogo Lucas Campos Martins', \\ Adriano Antunes de Souza Araújo ${ }^{4}$, Luiz Carlos Cides da Silva ${ }^{5}$, Marília dos Santos Bezerra4, \\ Ricardo Luiz Cavalcanti de Albuquerque-Júnior ${ }^{6}$, Eduardo Antonio Conde-Garcia ${ }^{1}$
}

\section{Affiliations}

1 Cardiobiophysics Research Laboratory, Department of Physiology, Federal University of Sergipe, Aracaju, SE, Brazil

2 Laboratory of Excitable Membranes and Cardiovascular Biology, Department of Biochemistry and Immunology, Federal University of Minas Gerais, Belo Horizonte, MG, Brazil

3 Biomedical Sciences Building, Laboratory of Electrophysiology, Federal University of São Paulo, Sao Paulo, Brazil

4 Laboratory for Pharmaceutical and Toxicology Studies, Department of Pharmacy, Federal University of Sergipe, Aracaju, Brazil

5 Thermal Analysis Laboratory, Institute of Chemistry, University of São Paulo, São Paulo, SP, Brazil

6 Laboratory of Morphology and Structural Biology, University Tiradentes, Aracaju, Brazil

Key words

Cladonia substellata, Cladoniaceae, usnic acid, lichen, heart function, $\mathrm{Ca}^{2+}$ currents

received 16.08 .2016

revised 30.04 .2017

accepted 18.05.2017

\section{Bibliography}

DOI https://doi.org/10.1055/s-0043-114423

Planta Med Int Open 2017; 4: e59-e65

(C) Georg Thieme Verlag KG Stuttgart · New York

ISSN 2509-9264

\section{Correspondence}

Carla Maria Lins Vasconcelos

Cardiobiophysics Research Laboratory

Department of Physiology

Federal University of Sergipe

Marechal Rondon Av.

Aracaju, SE, 49100-000

Brazil

Phone: + 55793194 6642, Fax: +55 7931946642

carlamlv@hotmail.com
Jader Santos Cruz

Laboratory of Excitable Membranes and Cardiovascular Biology Department of Biochemistry and Immunology Federal University of Minas Gerais, 6627, Antonio Carlos Av. Belo Horizonte, MG, 31270-901

Brazil

Phone: +55 31 34092668, Fax: +55 3134092615

jcruz@icb.ufmg.br

丹upporting information Details on the chemical characterization of UA from C. substellata are available online at http:// www.thieme-connect.de/products

\begin{abstract}
The scientific interest in (+)-usnic acid has grown because of its antitumor, cytotoxic, and antimicrobial activities as well as weight loss. However, overuse of usnic acid has been related with severe hepatotoxicity, making its use questionable. In this study, we decided to expand the knowledge of usnic acid biological activities by characterizing its effects on the mammalian myocardium as a potential pharmacological target. Usnic acid was isolated from samples of Cladonia substellata and submitted to chemical characterization. Molecular inclusion complexes of usnic acid with hydroxypropyl $\beta$-cyclodextrin were prepared to improve its water solubility. The effects of usnic acid on the atrial contractility and $\mathrm{Ca}^{2+}$ influx were carried out in the left atrium of guinea pigs and the effect of usnic acid on the L-type $\mathrm{Ca}^{2+}$ current was performed in rat ventricular cardiomyocytes enzymatically isolated. To evaluate the membrane integrity of cells subjected to usnic acid, we used histological procedures. Usnic acid reduced atrial contraction with an $\mathrm{EC}_{50}$ of $43.0 \pm 1.0 \mu \mathrm{M}$. This effect was related to a reduction of $\mathrm{Ca}^{2+}$ entry in myocardial cells. In isolated cardiac myocytes, usnic acid at $100 \mu \mathrm{M}$ inhibited the L-type $\mathrm{Ca}^{2+}$ current by $73.0 \%$. In addition, usnic acid caused an irreversible myocardial contracture, reflecting a serious disturbance of the intracellular $\mathrm{Ca}^{2+}$ homeostasis. Such an effect could not be ascribed to tissue death because cell membrane integrity was confirmed by histological observation. Taken together, our results show that usnic acid impairs cardiac function. Clearly more studies will be necessary to allow further applications of this natural product.
\end{abstract}




\section{Introduction}

Usnic acid (UA; 2,6-diacetyl-7,9-dihydroxy-8,9b-dimethyldibenzofuran-1,3[2H,9bH]-dione) is one of the most studied lichen secondary metabolites. Several biological properties have been ascribed to this compound including antibacterial [1,2], anti-Trypanosoma cruzi [3], antiviral [4], anti-inflammatory [5], apoptosis inducer [6], and antiproliferative [2, 7, 8]. UA is toxic to human lymphocytes and hepatocytes [6,9-13]. Scientific interest in UA has grown after a number of reports showing antiproliferative effects of UA for cancerous cell lines [14-17].

However, despite beneficial effects, there are few studies demonstrating that UA alters $\mathrm{Ca}^{2+}$ homeostasis, induces endoplasmic reticulum (ER) stress, and increases oxidative stress, and that these alterations are involved in UA-induced cellular damage $[18,19]$. Furthermore, several compounds of natural origin are $\mathrm{Ca}^{2+}$ channels blockers [20, 21].

UA has also been known to be a strong mitochondrial uncoupler, which could be related to its hepatotoxicity [12]. However, it has not been clarified whether UA causes toxicity in other organs such as the heart. For example, it is reported that a 14-day administration of UA ( $100 \mathrm{mg} / \mathrm{kg} /$ day) provoked mitochondrial swelling in cardiac myocytes in rats [22]. However, there are few studies determining whether UA has a pharmacological effect on the function of heart. Based on these results, we have attempted to determine the potential pharmacological effect of UA on heart function.

\section{Results}

The identity of usnic acid and its optical activity are reported in Supporting Information.

In the guinea pig left atrium, UA reduced the myocardium contractility in a concentration-dependent manner ( $\vee$ Fig. 1a). UA at $800 \mu \mathrm{M}$ strongly reduced the atrial force from $29.7 \pm 0.6 \mathrm{mgf} / \mathrm{mg}$ to $1.2 \pm 0.5 \mathrm{mgf} / \mathrm{mg}\left(96 \%, n=8, p<0.0001\right.$; $>$ Fig. 1 b) with an $E C_{50}$ of $43.0 \pm 1.0 \mu \mathrm{M}$. Nifedipine, used as a positive control, presented a very similar pattern, reducing the atrial contractile force from $28.3 \pm 2.1 \mathrm{mgf} / \mathrm{mg}$ to $2.5 \pm 0.7 \mathrm{mgf} / \mathrm{mg}$ (91\%, $\mathrm{p}<0.001$, $E C_{50}=1.1 \pm 1.0 \mu \mathrm{M}$; Fig. $\left.1 \mathbf{b}\right)$. UA is 39 -fold less potent than nifedipine. Furthermore, an increase of the atrial diastolic tension to $650.0 \pm 25.97 \mathrm{mgf}\left(\mathrm{EC}_{50}=589.8 \pm 10.3 \mu \mathrm{M}, \mathrm{n}=8\right.$; $>$ Fig. 1a,c) was observed after incubating the atrium with $800 \mu \mathrm{M} \cup \mathrm{A}$.

No significant histological differences between the control atria ( $\vee$ Fig. 2a,c) and the atria exposed to $800 \mu \mathrm{M} U A$ ( $\triangleright$ Fig. 2b,d) were observed. Furthermore, neither muscular necrosis nor interstitial fibrosis was seen.

As demonstrated in $>$ Fig. 3, UA abolishes the Bowditch effect. - Fig. 3a (i and ii) depicts representative records obtained before and after adding $70 \mu \mathrm{M}$ UA to the bath, respectively. $>$ Fig. 3a (i; control) shows an increase in the force amplitude from $197 \mathrm{mgf}$ (20 bpm) to $636 \mathrm{mgf}$ ( $80 \mathrm{bpm}$ ). However, when $70 \mu \mathrm{M}$ UA were added to the bath, the Bowditch phenomenon was completely abolished $\triangleright \mathbf{F i g}$. $\mathbf{3 a}$ (ii)]. Similar results were obtained on the other three atria ( $\triangleright$ Fig. $\mathbf{3 b}$ ) tested at rates from $20 \mathrm{bpm}$ to $120 \mathrm{bpm}$. Note that when $70 \mu \mathrm{M} \cup A$ were added to the bath solution, the atrial contractile force during the overdrive was greatly reduced to $3.33 \pm 3.21 \%$ of the control contractile force amplitude $(n=3$, $p<0.01)$. This result indicates that UA decreases the atrial contractile force by reducing $\mathrm{Ca}^{2+}$ influx in cardiac myocytes.

To further explore the idea that $\mathrm{UA}$ reduces $\mathrm{Ca}^{2+}$ influx we made use of another experimental approach. In order to examine that possibility, the extracellular $\mathrm{Ca}^{2+}$ concentration was changed in the absence and in the presence of UA at $100 \mu \mathrm{M}$. > Fig. 3c illustrates the expected positive inotropic response to increases in extracelIular $\mathrm{Ca}^{2+}$ concentration ( 0.5 to $5.0 \mathrm{mM}$ ). The calculated $\mathrm{EC}_{50}$ for $\mathrm{Ca}^{2+}$ was $0.69 \pm 0.42 \mathrm{mM}$. However, when the atria were preincubated with $100 \mu \mathrm{M} U \mathrm{UA}$, a rightward shift of the concentration-response curve for $\mathrm{Ca}^{2+}$ was observed and the $\mathrm{EC}_{50}$ increased to $1.28 \pm 0.24 \mathrm{mM}(\mathrm{p}<0.05)$. These data support the conclusion that the cardiodepressor effect of UA is related to a decrease in sarcolemmal $\mathrm{Ca}^{2+}$ influx.

Representative families of whole-cell L-type $\mathrm{Ca}^{2+}$ currents are illustrated in - Fig. $\mathbf{4 a}$ (Control) and $\mathbf{B}$ (in the presence of UA). Application of UA produced a concentration-dependent decrease of peak $\mathrm{I}_{\mathrm{Ca} \text {-L }}$ (mean data shown in $>$ Fig. 4c). $>$ Fig. $4 \mathbf{d}$ shows the effect of $1,10,30$, and $100 \mu \mathrm{M} \cup A$ on the mean $I-V$ relationship of $I_{C a-}$ $\left\llcorner\right.$. UA decreased the $I_{C a-L}$ amplitude over the entire voltage range tested but did not shift the I-V relationship. The reduction of the $\mathrm{I}_{\mathrm{Ca}, \mathrm{L}}$ can account for the negative inotropic effect elicited by $\mathrm{UA}$ in the heart.

\section{Discussion}

This study reports new findings on the effect of UA on atrial contractility as well as on the L-type $\mathrm{Ca}^{2+}$ current in myocardial cells. We have demonstrated that UA is a potent depressor of cardiac contractility. In addition, concentrations higher than $300 \mu \mathrm{M}$ induced a sustained and irreversible contracture during the diastolic phase. These results cannot be explained in response to changes in the $\mathrm{pH}$ of the Tyrode's solution due to the use of an acidic substance (UA pKa $=4.4$ ), as the $\mathrm{pH}$ remained unchanged even at $1200 \mu \mathrm{M}$ UA (data not shown). Neither can it be attributed to cytotoxicity. There are some studies indicating a cytotoxic effect for UA at concentrations in the micromolar range $[12,17]$. However, the histological analyses revealed no significant differences between the control atria and those subjected to UA (at $800 \mu \mathrm{M})$. Viable myocardial cells were observed showing preserved structures, including the pattern of striations that is an important parameter for cellular integrity. Therefore, UA effects on mammalian myocardium are not completely due to its claimed cytotoxicity.

This is the first report demonstrating that UA decreases cardiac contractility by blocking voltage-dependent L-type $\mathrm{Ca}^{2+}$ channels. Our data showed that when the atrium was incubated with UA, the Bowditch effect was critically impaired, probably due to reduction of $\mathrm{Ca}^{2+}$ entry into the myocardial cells. Following this line of reasoning, we performed experiments to evaluate whether positive inotropic interventions could be attenuated by UA. Our results showed that UA drastically affected positive inotropism induced by $\mathrm{Ca}^{2+}$, corroborating the hypothesis that UA can reduce the sarcolemmal $\mathrm{Ca}^{2+}$ inward current.

In cardiac muscle, $\mathrm{Ca}^{2+}$ influx through the sarcolemmal membrane is essential for triggering $\mathrm{Ca}^{2+}$ release from the sarcoplasmic reticulum (SR). The combination of $\mathrm{Ca}^{2+}$ influx and $\mathrm{SR} \mathrm{Ca}^{2+}$ release 

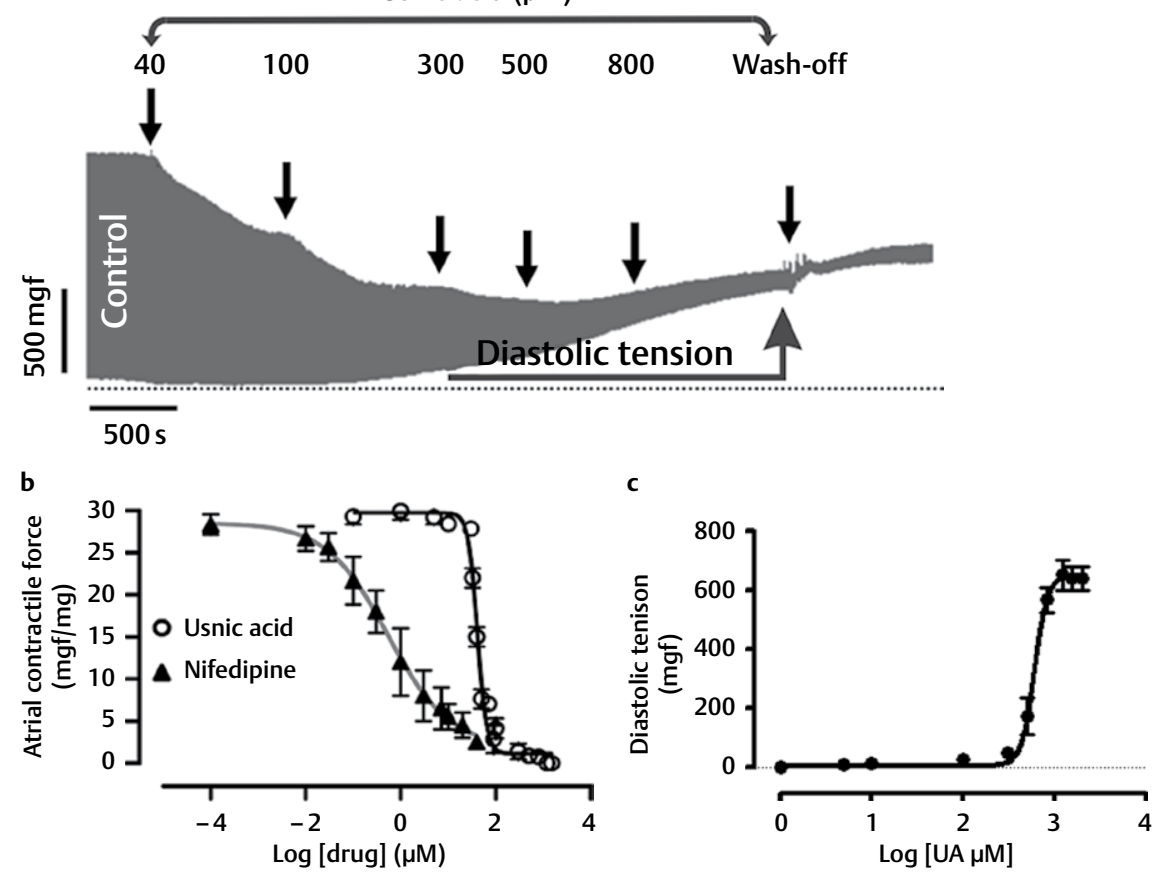

- Fig. 1 The effects of (+)-UA on guinea pig left atrium contractile force. a Exemplar of an original record of a negative inotropic effect elicited by $(+)$-UA. At concentrations above $300 \mu \mathrm{M}$, an increase in diastolic tension is also observed. $\mathbf{b}$ Concentration-response curves of UA $\left(E C_{50}=43.0 \pm 1.0 \mu \mathrm{M}, \mathrm{n}=8\right.$, open circles) and nifedipine $\left(\mathrm{EC}_{50}=1.1 \pm 1.0 \mu \mathrm{M}, \mathrm{n}=8\right.$, black triangles $)$. $\mathrm{c}$ Concentration-response curve of UA on diastolic tension ( $\mathrm{EC}_{50}=589.8 \pm 10.3 \mu \mathrm{M}, \mathrm{n}=8$, black circles).

promotes an increase in the free intracellular $\mathrm{Ca}^{2+}$ concentration, causing the muscle to contract [23]. The relationship between UA and the voltage-dependent L-type $\mathrm{Ca}^{2+}$ current was established by direct measurements of the L-type $\mathrm{Ca}^{2+}$ current in isolated cardiomyocytes. Our data showed that UA reduced the L-type $\mathrm{Ca}^{2+}$ current by $73 \%$, which explains the negative inotropism.

We speculate that the diastolic contracture observed at high concentrations of UA may be due to an impaired $\mathrm{Ca}^{2+}$ reuptake from the sarcoplasm to SR lumen by sarco(endo)plasmic reticulum $\mathrm{Ca}^{2+}$-ATPase (SERCA). We can argue that $\mathrm{Ca}^{2+}$ uptake is dependent on the levels of intracellular ATP, and a decrease in ATP leads to a decrease in SERCA activity and contributes to an increase in cytosolic $\mathrm{Ca}^{2+}$.

These new findings offer additional mechanistic insight into how heart contractility is altered by UA and raise further questions about the safety of its medicinal use.

\section{Materials and Methods}

\section{Lichenic material}

Samples of Cladonia substellata Vain. (Cladoniaceae) were collected in March (fall season) in the National Park of the Itabaiana Ridge (180-670 m; $10^{\circ} 41^{\prime 2} 22^{\prime \prime S}$; $37^{\circ} 24^{\prime} 10^{\prime \prime W}$ ), Itabaiana, Sergipe, Brazil. They were identified by Dr. Marcelo Pinto Marcelli, Head of the Mycology and Lichenology Section of the Institute of Botany, Univer- sity of São Paulo, São Paulo, Brazil, where a voucher specimen is stored (Deposit \#SP393249).

\section{Chemical characterization of usnic acid from Clado- nia substellata}

UA was chemically identified by the following procedures: 1) elemental analysis for carbon, hydrogen, and nitrogen content (Perkin-Elmer Analyzer, Model 2400), 2) NMR (Brucker DRX 500 spectrometer, ${ }^{1} \mathrm{H}: 500 \mathrm{MHz} ;{ }^{13} \mathrm{C}: 125 \mathrm{MHz}$ ), 3) X-ray diffraction (XRD) patterns (Siemens, Model D5000, tube of $\mathrm{CuK}_{\alpha}$ ) with measurements performed from 3 to $65^{\circ}(2 \theta)$ and $1 \mathrm{~s}$ pass time using the Powder X-ray diffraction method, 4) infrared absorption (FTIR), and 5) thermal analysis procedures [thermogravimetry (TG), differential thermogravimetry (DTG), differential scanning calorimetry (DSC)] performed according to Nunes et al. [24]. The enantiomeric form of UA isolated from C. substellata was determined via polarimetry (Polarimeter Jasco Model P-2000). The original spectra are available as Supporting Information.

\section{Water solubilization of usnic acid}

The water solubility of UA was improved by dissolving it in hydroxypropyl- $\beta$-cyclodextrin (HP $\beta C$ ) following the procedure described by Kristmundsdóttir et al. [25]. The HPBC interaction with UA was previously demonstrated [26]. Our results showed that HPBC reduced the atrial force slightly only at high concentrations $(800 \mu \mathrm{M})$. 


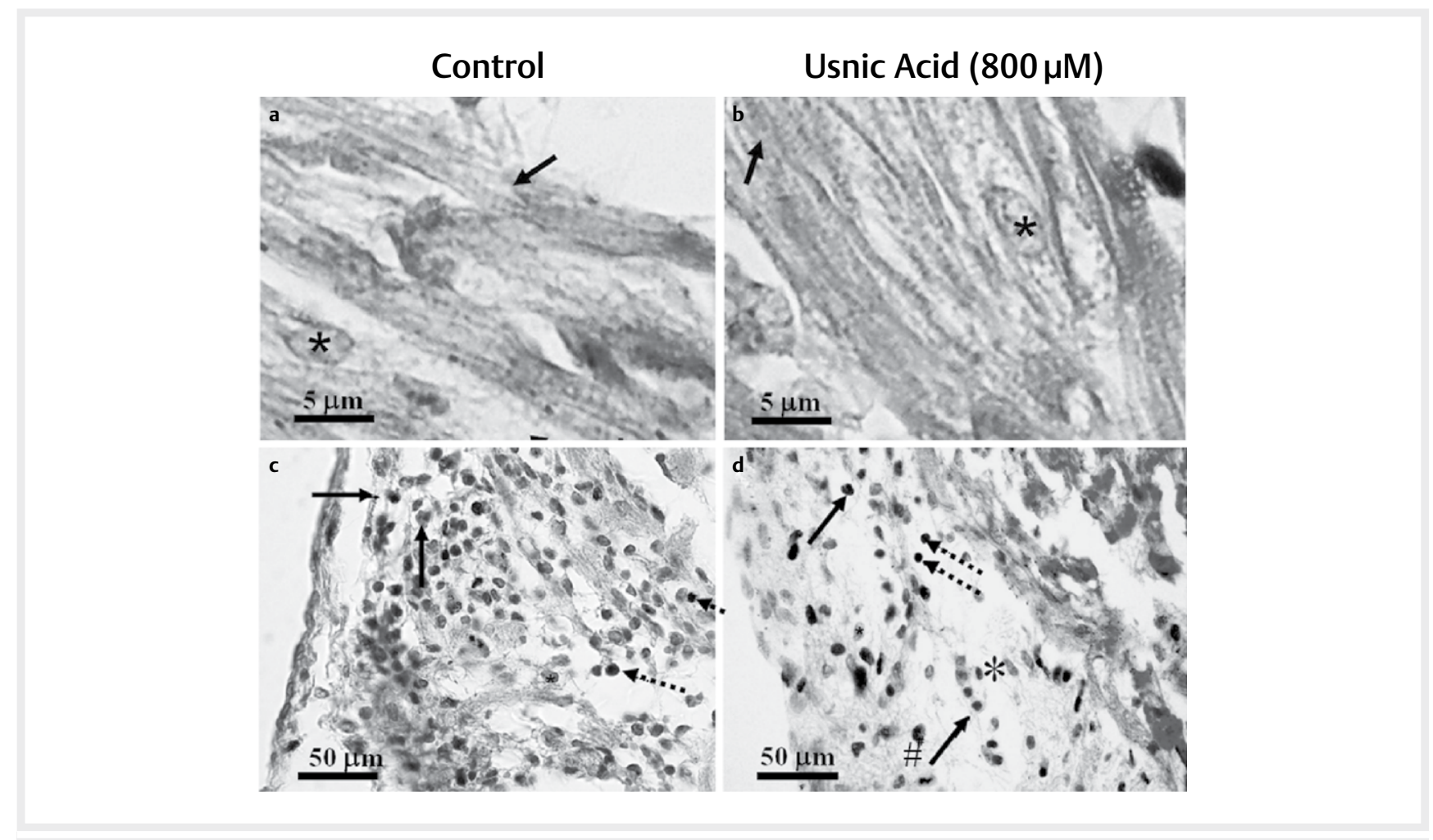

- Fig. 2 (+)-UA did not affect cellular integrity. Control group (a) and $800 \mu \mathrm{M}$ UA group (b) showing rabdomyocytes $\left({ }^{*}\right)$ with well-defined nuclei and transverse striations (arrows). Control group (c) and $800 \mu \mathrm{M}(+)$-UA group (d) depicting infiltrate in the stromal cardiac connective tissue composed of lymphocytes (dotted arrows), plasma cells (full arrows), and macrophages (\#) in addition to fibroblasts $\left({ }^{*}\right)$.

a

(i) Control

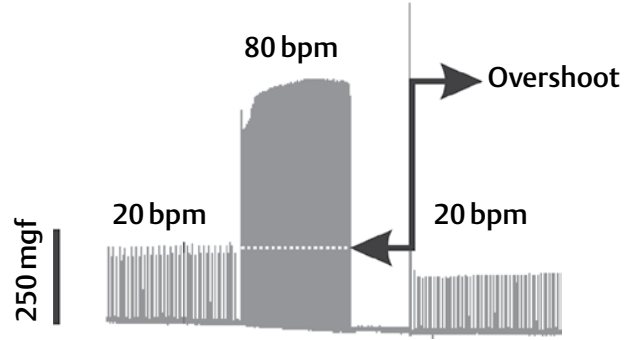

(ii) Usnic Acid

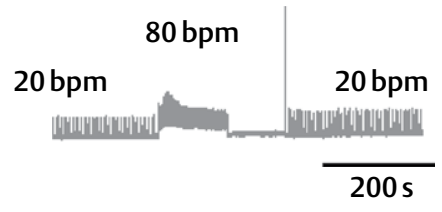

b
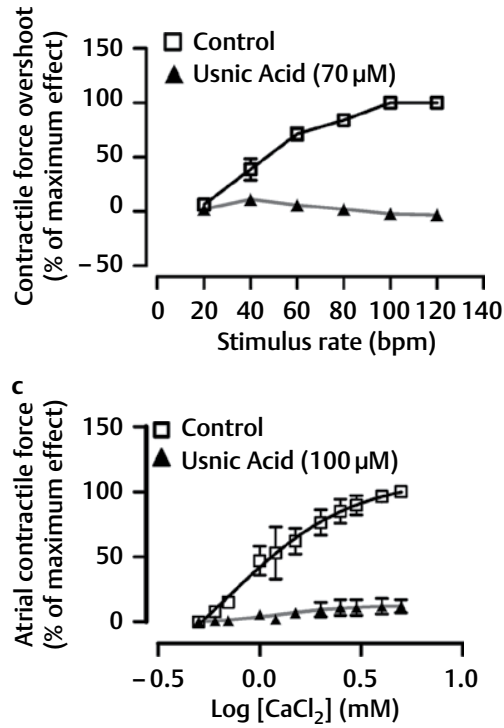

Fig. 3 Bowditch phenomenon is abolished by (+)-UA. a Example of atrial contractile force recordings showing the Bowditch phenomenon promoted by a sudden increase of the stimulation rate from 20 to $80 \mathrm{bpm}$ (i: control and ii: in the presence of UA). b Average contractile force overshoot as a function of different pacing rates $(n=3)$. $c$ The effects of $(+)$-UA on the concentration-response curves for the positive inotropic effects of $\mathrm{CaCl}_{2}$. At $100 \mu \mathrm{M},(+)$-UA significantly reduced the positive inotropic effect of $\mathrm{CaCl}_{2}(n=3)$. 


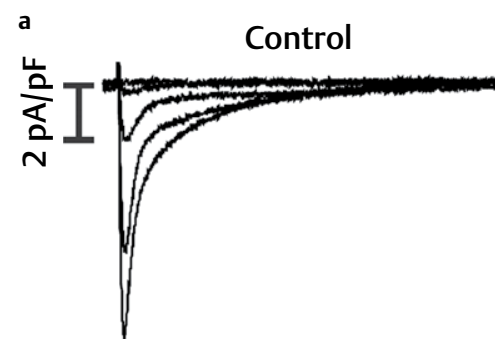

b
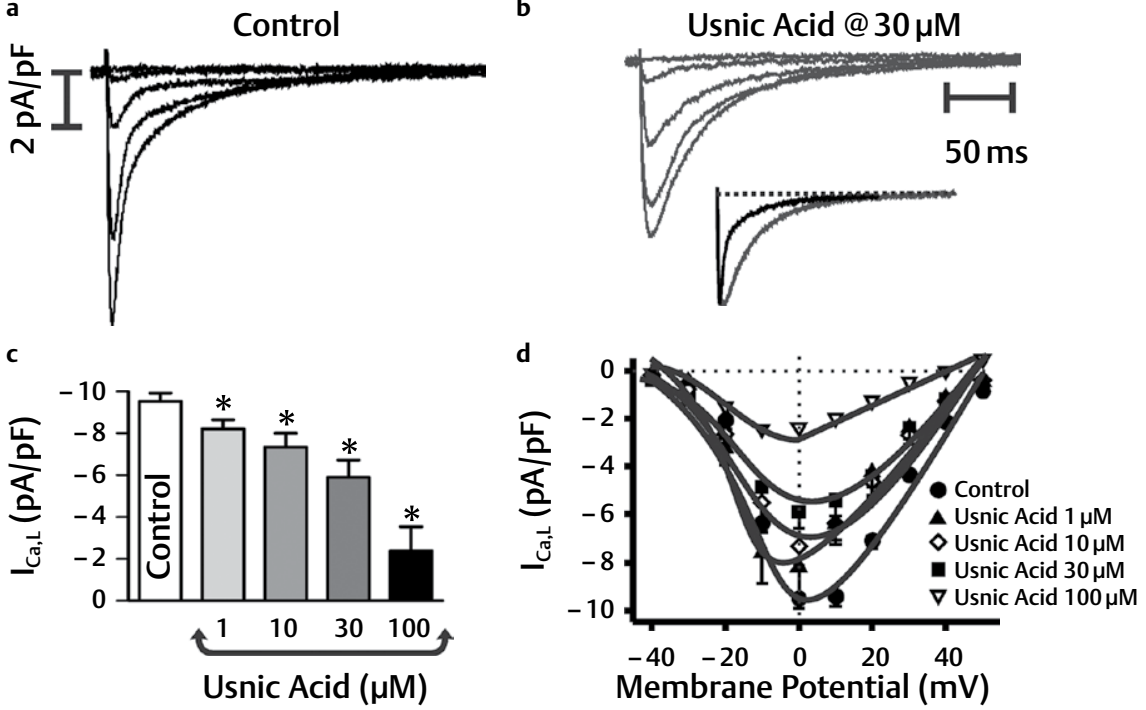

- Fig. 4 (+)-UA inhibits L-type $\mathrm{Ca}^{2+}$ currents. Representative L-type $\mathrm{Ca}^{2+}$ current recordings in the absence (a Control) and in the presence of $(+)$-UA $(\mathbf{b} 30 \mu \mathrm{M})$. c Average L-type $\mathrm{Ca}^{2+}$ current density at $0 \mathrm{mV}$ test pulse at $1,10,30$, and $100 \mu \mathrm{M}(+)-\mathrm{UA}\left({ }^{*} \mathrm{p}<0.05\right)$. d Average L-type Ca ${ }^{2+} \mathrm{cur}-$ rent density vs. voltage relationships obtained at different $(+)$-UA concentrations. Data points are the mean \pm SE.

\section{Myocardial contractility}

The effects of UA on myocardial inotropism were carried out using the left atrium of guinea pigs (Cavia porcellus, male, $400-500 \mathrm{~g}$ ), which was mounted in a vertical organ bath for contractile recordings [27]. Briefly, guinea pigs were sacrificed by decapitation, the heart was quickly removed, and the left atria were mounted in an organ chamber for the contractile force recordings. The atria, under $1 \mathrm{gf}$ tension and electrically stimulated $(2 \mathrm{~Hz})$, were immersed in oxygenated Tyrode's solution $\left(29 \pm 0.1{ }^{\circ} \mathrm{C}, 95 \% \mathrm{O}_{2}\right.$ and $\left.5 \% \mathrm{CO}_{2}\right)$. The atrial contraction force was recorded with an isometric force transducer (HP FTA 10-1 Sunborn, HP 8805B). The contractile signals were amplified by an HP7754B Carrier Amplifier and then digitalized in an A/D converter (DATAQ DI400, DI 205, WINDAQ PRO Acquisition) before being stored in a computer to be processed offline. The experimental setup is described in [28]. The following experimental procedures were performed: 1 ) concentration-response curve for UA, using nifedipine as the positive control, 2) effect of UA on the positive staircase (Bowditch phenomenon) elicited by a sudden increase of the stimulation rate (control rate: $12 \mathrm{bpm}$; test rate ranging from $20 \mathrm{bpm}$ to $120 \mathrm{bpm}$ ), and 3) effect of $U A$ on the concentration-response curve for $\mathrm{CaCl}_{2}$ (ranging from $0.5 \mathrm{mM}$ to $5.0 \mathrm{mM}$ ). The Bowditch phenomenon is characterized by an increase of the myocardial force occurring when the rate of stimulation is suddenly increased. It was demonstrated that the resulting contractile force enhancement is due to an increase in $\mathrm{Ca}^{2+}$ influx into myocardial cells [28-31].

\section{Histological analysis}

Histological procedures were used to evaluate the membrane integrity of cells subjected to a high concentration of UA $(800 \mu \mathrm{M})$. The experiments were performed on right and left guinea pig atria mounted separately in different organ baths. The right atrium was used as a control and the left atrium was used as the test sample ( $800 \mu \mathrm{M}$ UA for $20 \mathrm{~min})$. In the chambers, both atria were bathed with control Tyrode's solution $\left(27 \pm 0.1^{\circ} \mathrm{C}\right)$ under a resting tension of $1 \mathrm{gf}$ and subjected to electrical field stimulation with suprathreshold pulses $(2 \mathrm{~Hz})$. After that time, the atria were fixed in formaldehyde ( $10 \%, \mathrm{pH}=7.4)$, sliced, and stained with hematoxylin-eo$\sin$. Histopathological analysis was performed with an optical microscope (Olympus BX31) coupled to an edge detector.

\section{Electrophysiological studies}

Isolation of rat ventricular cardiomyocytes

To study the effect of UA on the L-type $\mathrm{Ca}^{2+}$ current $\left(\mathrm{I}_{\mathrm{Ca}, \mathrm{L}}\right)$, rat ventricular cardiomyocytes were enzymatically isolated [32]. Briefly, isolated hearts were subjected to aortic perfusion with a $\mathrm{Ca}^{2+}$-free solution ( $5 \mathrm{~min}$ ) and then digested in a solution containing collagenase (Worthington, Type II) to dissociate the myocardial cells. Cardiomyocytes were then obtained and stored at room temperature. The cells were used in the first $4-6 \mathrm{~h}$ after isolation. Only cells that were $\mathrm{Ca}^{2+}$ tolerant, rod-shaped, and showed clear cross striations were used for experimentation.

\section{Patch-clamp recordings}

Whole-cell patch-clamp recordings were obtained using an EPC9.2 patch-clamp amplifier (HEKA Electronics). After attaining the tight-seal whole-cell configuration, 3 to $5 \mathrm{~min}$ were allowed to equilibrate the cell interior with the pipette solution. The recording electrode resistance ranged from 1.0 to $1.5 \mathrm{M} \Omega$, and experiments were carried out at room temperature $\left(24-27^{\circ} \mathrm{C}\right)$. Cell capacitance and series resistance were compensated before measuring the ionic current. The records were low-pass filtered $(2.9 \mathrm{kHz})$ 
and sampled at $10 \mathrm{kHz}$. Cardiomyocytes showing a series resistance (Rs) larger than $10 \mathrm{M} \Omega$ were discarded. The Rs of selected cardiomyocytes was routinely compensated for by 40 to $70 \%$ before measuring the $\mathrm{I}_{\mathrm{Ca}, \mathrm{L}}$. This measurement was performed using recording pipettes filled with internal solution (see composition below) and using the bath solution as the external solution (see composition below). The pulse protocol was performed as follows: first, the membrane potential was stepped from a holding potential of $-80 \mathrm{mV}$ to $-40 \mathrm{mV}$, where it remained for $50 \mathrm{~ms}$ to inactivate the $\mathrm{Na}^{+}$channels. Then, the cell was clamped at different voltages from -40 to $+50 \mathrm{mV}$ for $300 \mathrm{~ms}$ in $10 \mathrm{mV}$ steps.

\section{Solutions and reagents}

Tyrode's solution (in $\mathrm{mM}$ ): $120.0 \mathrm{NaCl}, 2.7 \mathrm{KCl}, 0.9 \mathrm{MgCl}_{2}, 11.9$ $\mathrm{NaHCO}_{3}, 1.37 \mathrm{CaCl}_{2}, 5.5$ Glucose, $0.4 \mathrm{NaH}_{2} \mathrm{PO}_{4}$. Calcium-free solution (in mM): $130.0 \mathrm{NaCl}, 5.4 \mathrm{KCl}, 0.5 \mathrm{MgCl}_{2}, 0.33 \mathrm{NaH}_{2} \mathrm{PO}_{4}, 3.0$ pyruvate, 22.0 glucose, and 25.0 HEPES, pH 7.4 adjusted with $\mathrm{NaOH}$. Digest solution: prepared by adding $1 \mathrm{mg} / \mathrm{mL}$ type II collagenase (Worthington Biochemical Co.) to the calcium-free solution. External solution (in mM): $140 \mathrm{NaCl}, 5.4 \mathrm{KCl}, 1 \mathrm{MgCl}_{2}, 1.8$ $\mathrm{CaCl}_{2}, 10$ HEPES, 10 glucose, and $\mathrm{pH}$ set to 7.4 with $\mathrm{NaOH}$. Internal pipette solution (in $\mathrm{mM}$ ): $120.0 \mathrm{CsCl}, 20.0 \mathrm{TEACl}, 5.0 \mathrm{NaCl}, 10.0$ HEPES, 5.0 EGTA, pH adjusted with $\mathrm{CsOH}$ to 7.2. Nifedipine (purity $\geq 98 \%$ ) was purchased from Sigma-Aldrich. Chloroform, ethanol, and reagents were of the highest grade available and were purchased from Sigma-Aldrich, Merck, J. T. Backer, Amresco, or VETEC.

\section{Ethical committee approval}

This work was previously approved by the Ethical Committee on Animal Research of the Federal University of Sergipe (CEPA/UFS, protocol \#77/11, September 9, 2011). Animal handling was in compliance with the Principles of Laboratory Animal Care (NIH publication 86-23, revised 1985; http://oacu.od.nih.gov/regs/index.htm).

\section{Statistical analysis}

One-way ANOVA (MINITAB, Minitab Inc., EUA) followed by Tukey's post hoc test was employed to determine the significance of the difference between means. Data are reported as means $\pm \mathrm{SE}$.

\section{Acknowledgments}

The authors are in debt to the Conselho Nacional do Desenvolvimento Científico e Tecnológico (CNPq/MCT, DF/Brazil, Edital Universal 14/2008, Grant \#478581/2008-4), Centrais Elétricas Brasileiras (ELETROBRAS/MME, DF/Brazil, Grant \#23113.009351/03-67), Fundação de Amparo à Pesquisa do Estado de Sergipe (FAPITEC, Aracaju/SE, Brazil), Coordenação do Aperfeiçoamento do Pessoal de Nível Superior (CAPES), and Universidade Federal de Sergipe (UFS, Aracaju/Sergipe, Brazil) for financial support. D. R. C is supported by Fundação de Amparo a Pesquisa do Estado de São Paulo (FAPESP). J. S. C is a research fellow from CNPq.

\section{Conflict of Interest}

The authors declare no conflict of interest.

\section{References}

[1] Nybakken L, Julkunen-Tiitto R. UV-B induces usnic acid in reindeer lichens. Lichenologist 2006; 38: 477-486

[2] Ivanova V, Bačkor M, Dahse HM, Graefe U. Molecular structural studies of lichen substances with antimicrobial, antiproliferative, and cytotoxic effects from Parmelia subrudecta. Prep Biochem Biotechnol 2010; 40: 377-388

[3] De Carvalho E, Andrade P, Silva N, Pereira E, Figueiredo R. Effect of usnic acid from the lichen Cladonia substellata on Trypanosoma cruzi in vitro: an ultrastructural study. Micron 2005; 36: 155-161

[4] Scirpa P, Scambia G, Masciullo V, Battaglia F, Foti E, Lopez R, Villa P, Malecore M, Mancuso S. A zinc sulfate and usnic acid preparation used as post-surgical adjuvant therapy in genital lesions by Human Papillomavirus. Minerva Ginecol 1999; 51: 255-260

[5] Jin JQ, Li CQ, He LC. Down-regulatory effect of usnic acid on nuclear factor-kB-dependent tumor necrosis factor- $\alpha$ and inducible nitric oxide synthase expression in lipopolysaccharide-stimulated macrophages RAW 264.7. Phytother Res 2008; 22: 1605-1609

[6] Bazin MA, Le Lamer AC, Delcros JG, Rouaud I, Uriac P, Boustie J, Corbel JC, Tomasi S. Synthesis and cytotoxic activities of usnic acid derivatives. Bioorg Med Chem 2008; 16: 6860-6866

[7] Burlando B, Ranzato E, Volante A, Appendino G, Pollastro F, Verotta L. Antiproliferative effects on tumour cells and promotion of keratinocyte wound healing by different lichen compounds. Planta Med 2009; 75: 607-613

[8] Ribeiro-Costa RM, Alves AJ, Santos NP, Nascimento SC, Gonçalves EC, Silva NH, Honda NK, Santos-Magalhães NS. In vitro and in vivo properties of usnic acid encapsulated into PLGA-microspheres. J Microencapsul 2004; 21: 371-384

[9] Foti RS, Dickmann LJ, Davis JA, Greene RJ, Hill J], Howard ML, Pearson JT, Rock DA, Tay JC, Wahlstrom JL, Slatter JG. Metabolism and related human risk factors for hepatic damage by usnic acid containing nutritional supplements. Xenobiotica 2008; 38: 264-280

[10] da Silva Santos NP, Nascimento SC, Wanderley MSO, Pontes-Filho NT, da Silva JF, de Castro CMMB, Pereira EC, da Silva NH, Honda NK, Santos-Magalhães NS. Nanoencapsulation of usnic acid: An attempt to improve antitumour activity and reduce hepatotoxicity. Eur J Pharm Biopharm 2006; 64: 154-160

[11] Koparal A, Ayaz Tüylü B, Türk H. In vitro cytotoxic activities of (+)-usnic acid and (-)-usnic acid on V79, A549, and human lymphocyte cells and their non-genotoxicity on human lymphocytes. Nat Prod Res 2006; 20: 1300-1307

[12] Han D, Matsumaru K, Rettori D, Kaplowitz N. Usnic acid-induced necrosis of cultured mouse hepatocytes: Inhibition of mitochondrial function and oxidative stress. Biochem Pharmacol 2004; 67: 439-451

[13] Pramyothin P, Janthasoot W, Pongnimitprasert N, Phrukudom S, Ruangrungsi N. Hepatotoxic effect of $(+)$ usnic acid from Usnea siamensis Wainio in rats, isolated rat hepatocytes and isolated rat liver mitochondria. J Ethnopharmacol 2004; 90: 381-387

[14] Mayer M, O’Neill MA, Murray KE, Santos-Magalhães NS, Carneiro-Leão AMA, Thompson AM, Appleyard VC. Usnic acid: A non-genotoxic compound with anti-cancer properties. Anticancer Drugs 2005; 16: 805-809

[15] O’Neill M, Mayer M, Murray K, Rolim-Santos H, Santos-Magalhães N, Thompson AM, Appleyard VC. Does usnic acid affect microtubules in human cancer cells? Braz J Biol 2010; 70: 659-664

[16] Bačkorová M, Bačkor M, Mikeš J, Jendželovský R, Fedoročko P. Variable responses of different human cancer cells to the lichen compounds parietin, atranorin, usnic acid and gyrophoric acid. Toxicol In Vitro 2011; 25: 37-44 
[17] Einarsdóttir E, Groeneweg J, Björnsdóttir GG, Harðardottir G, Omarsdóttir S, Ingólfsdóttir K, Ögmundsdóttir HM. Cellular mechanisms of the anticancer effects of the lichen compound usnic acid. Planta Med 2010; 76: 969-974

[18] Chen S, Zhang Z, Wu Y, Shi Q, Yan H, Mei N, Tolleson WH, Guo L. Endoplasmic reticulum stress and store-operated calcium entry contribute to usnic acid-induced toxicity in hepatic cells. Toxicol Sci 2015; 146: 116-126

[19] Chen S, Zhang Z, Qing T, Ren Z, Yu D, Couch L, Ning B, Mei N, Shi L, Tolleson WH, Guo L. Activation of the Nrf2 signaling pathway in usnic acid-induced toxicity in HepG2 cells. Arch Toxicol 2017; 91: 12931307

[20] Vuorela H, Vuorela P, Törnquist K, Alaranta S. Calcium channel blocking activity: Screening methods for plant derived compounds. Phytomedicine 1997; 4: 167-180

[21] de Menezes-Filho JE, Gondim AN, Cruz JS, Souza AA, Santos JN, Conde-Garcia EA, de Sousa DP, Santos MS, de Oliveira ED, de Vasconcelos CM. Geraniol blocks calcium and potassium channels in the mammalian myocardium: Useful effects to treat arrhythmias. Basic Clin Pharmacol Toxicol 2014; 115: 534-544

[22] Yokouchi Y, Imaoka M, Niino N, Kiyosawa N, Sayama A, Jindo T. (+)-Usnic acid-induced myocardial toxicity in rats. Toxicol Pathol 2015; 43: 424-434

[23] Bers DM. Cardiac excitation-contraction coupling. Nature 2002; 415 : 198-205

[24] Nunes PS, Bezerra MS, Costa LP, Cardoso JC, Albuquerque RLC Jr., Rodrigues MO, Borin Barin G, Amaral da Silva F, Araújo AAS. Thermal characterization of usnic acid/collagen-based films. J Therm Anal Calori 2010; 99: 1011-1014
[25] Kristmundsdóttir T, Jónsdóttir E, Ögmundsdóttir HM, Ingólfsdóttir K. Solubilization of poorly soluble lichen metabolites for biological testing on cell lines. Eur J Pharm Sci 2005; 24: 539-543

[26] Segura-Sanchez F, Bouchemal K, Lebas G, Vauthier C, Santos-Magalhaes NS, Ponchel G. Elucidation of the complexation mechanism between (+)-usnic acid and cyclodextrins studied by isothermal titration calorimetry and phase-solubility diagram experiments. J Mol Recogn 2009; 22: 232-241

[27] Vasconcelos CM, Araújo MS, Silva BA, Conde-Garcia EA. Negative inotropic and chronotropic effects on the guinea pig atrium of extracts obtained from Averrhoa carambola L. leaves. Braz J Med Biol Res 2005; 38: $1113-1122$

[28] Passos AG, Gondim AN, Roman-Campos D, Cruz JS, Conde-Garcia EA, Araújo Neto V, Estevam CS, Cerqueira SVS, Brandão GC, Oliveira AB, Vascolcelos $C M$. The positive inotropic effect of the ethyl acetate fraction from Erythrina velutina leaves on the mammalian myocardium: the role of adrenergic receptors. J Pharm Pharmacol 2013; 65: 928-936

[29] Nayler WG, Merrillees N. Cellular exchange of calcium. In: Harris P, Opie L.eds. Calcium and the heart. London: Academic Press; 1971: 24-65

[30] Endoh M. Force-frequency relationship in intact mammalian ventricular myocardium: physiological and pathophysiological relevance. Eur J Pharmacol 2004; 500: 73-86

[31] Monasky MM, Janssen PM. The positive force-frequency relationship is maintained in absence of sarcoplasmic reticulum function in rabbit, but not in rat myocardium. J Comp Physiol B 2009; 179: 469-479

[32] Roman-Campos D, Campos AC, Gioda C, Campos P, Medeiros MA, Cruz JS. Cardiac structural changes and electrical remodeling in a thiamine-deficiency model in rats. Life Sci 2009; 84: 817-824 